\title{
Delphinidin inhibits angiogenesis through the suppression of HIF-1 $\alpha$ and VEGF expression in A549 lung cancer cells
}

\author{
MUN-HYEON KIM $^{1 *}$, YUN-JEONG JEONG ${ }^{1 *}$, HYUN-JI CHO ${ }^{1,2}$, HYANG-SOOK HOE $^{2}$, \\ KWAN-KYU PARK ${ }^{1}$, YOON-YUB PARK ${ }^{1}$, YUNG HYUN CHOI ${ }^{3}, \mathrm{CHEORL-HO} \mathrm{KIM}^{4}$, \\ HYEUN-WOOK CHANG ${ }^{5}$, YOUNG-JA PARK ${ }^{6}$, IL-KYUNG CHUNG ${ }^{7}$ and YOUNG-CHAE CHANG ${ }^{1}$

\begin{abstract}
${ }^{1}$ Research Institute of Biomedical Engineering and Department of Medicine, Catholic University of Daegu School of Medicine, Daegu 705-718; ${ }^{2}$ Department of Neural Development and Disease, Korea Brain Research Institute (KBRI), Daegu 701-300; ${ }^{3}$ Department of Biochemistry, College of Oriental Medicine, Dongeui University, Busan 614-052;

${ }^{4}$ Department of Biological Sciences, Sungkyunkwan University, Suwon, Gyeonggi 440-746; ${ }^{5}$ College of Pharmacy, Yeungnam University, Gyeongsan, Gyeongbuk 701-947; ${ }^{6}$ Department of Clinical Pathology, Sorabol College, Gyeongju, Gyeongbuk 780-711; ${ }^{7}$ Department of Biotechnology, Catholic University of Daegu, Gyeongsan,
\end{abstract} Gyeongbuk 712-702, Republic of Korea

Received June 16, 2016; Accepted August 9, 2016

DOI: $10.3892 / o r .2016 .5296$

\begin{abstract}
Delphinidin, a polyphenol that belongs to the group of anthocyanidins and is abundant in many pigmented fruits and vegetables, possesses important antioxidant, anti-inflammatory, anti-mutagenic and anticancer properties. In the present study, we investigated the inhibitory effects of delphinidin on vascular endothelial growth factor (VEGF) expression, an important factor involved in angiogenesis and tumor progression, in A549 human lung cancer cells. Delphinidin inhibited $\mathrm{CoCl}_{2}$ - and epidermal growth factor (EGF)-induced VEGF mRNA expression and VEGF protein production. Delphinidin also decreased $\mathrm{CoCl}_{2}$ - and EGF-stimulated expression of hypoxia-inducible factor (HIF)- $1 \alpha$, which is a transcription factor of VEGF. Delphinidin suppressed
\end{abstract}

Correspondence to: Professor Young-Chae Chang, Research Institute of Biomedical Engineering and Department of Medicine, Catholic University of Daegu School of Medicine, 3056-6 Daemyung-4-Dong, Nam-gu, Daegu 705-718, Republic of Korea E-mail: ycchang@cu.ac.kr

*Contributed equally

Abbreviations: VEGF, vascular endothelial growth factor; EGF, epidermal growth factor; EGFR, EGF receptor; HIF, hypoxia-inducible factor; VHL, von Hippel-Lindau; HREs, hypoxia-response elements; mTOR, mammalian target of rapamycin; 4E-BP1, eukaryotic initiation factor 4E-binding protein 1; ERK, extracellular signal-regulated protein kinase; MAPK, mitogen-activated protein kinase; PI3K,

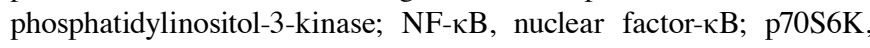
p70S6 kinase

Key words: delphinidin, EGF, angiogenesis, HIF-1 $\alpha$, VEGF
$\mathrm{CoCl}_{2}$ - and EGF-induced hypoxia-response element (HRE) promoter activity, suggesting that the inhibitory effects of delphinidin on VEGF expression are caused by the suppression of the binding of HIF-1 to the HRE promoter. We also found that delphinidin specifically decreased the $\mathrm{CoCl}_{2}$ - and EGF-induced HIF-1 $\alpha$ protein expression by blocking the ERK and PI3K/Akt/mTOR/p70S6K signaling pathways, whereas the p38-mediated pathways were not involved. In animal models, EGF-induced new blood vessel formation was significantly inhibited by delphinidin. Therefore, our results indicate that delphinidin has a potentially new role in anti-angiogenic action by inhibiting HIF-1 $\alpha$ and VEGF expression.

\section{Introduction}

Angiogenesis is the formation of new blood vessels. It is essential for the delivery of nutrients and oxygen to tumor cells that are distant from existing blood vessels. Angiogenesis is involved in the pathogenesis of many diseases such as cancer, atherosclerosis, and diabetic retinopathy (1-3). It plays an especially important role in tumor growth, metastasis, and invasion. The development of angiogenesis is associated with a poor tumor prognosis (4). To initiate tumor angiogenesis, angiogenic growth factors, including vascular endothelial growth factors (VEGFs), fibroblast growth factors, and platelet-derived growth factors, must be secreted (5). Among angiogenic growth factors, VEGF is highly specific and plays a crucial role in the angiogenesis of tumors (6). VEGF is induced by various pathophysiological conditions, including low oxygen tension (hypoxia), and several growth factors, such as epidermal growth factor (EGF), transforming growth factor $\alpha$ and $\beta$, and insulin-like growth factor 1 (7). Hypoxia, the prime stimulus of angiogenesis, enhances stabilization of hypoxia-inducible factors (HIFs) and their binding to VEGF promoter elements. Activated HIF induces VEGF transcription (8). 
HIF- $1 \alpha$ is an oxygen-dependent transcription factor that plays an important role in cellular adaptation to hypoxia and in tumor progression. It is composed of the HIF-1 $\alpha$ subunit and the HIF-1 $\beta$ subunit (9). HIF-1 $\alpha$ expression is regulated by oxygen pressure, whereas HIF-1 $\beta$ expression is unaffected by changes in oxygen tension (3). In addition, HIF-1 $\alpha$ is overexpressed in more than $70 \%$ of solid human tumors $(10,11)$. Oxygen-dependent prolyl hydroxylases catalyze polyubiquitinylation by the von Hippel-Lindau (VHL) protein E3 ligase complex and consequent HIF-1 $\alpha$ degradation in normoxic conditions (12). In hypoxia, HIF-1 $\alpha$ is not degraded due to a block in prolyl hydroxylation. Stabilized HIF-1 $\alpha$ forms an active complex with HIF-1 $\beta$ in the nucleus and activates the transcription of target genes such as VEGF by binding to the promoter region of hypoxia-response elements (HREs) (13).

In addition to hypoxia, HIF-1 $\alpha$ expression is induced by cytokines, hormones, and growth factors that stimulate tyrosine kinase receptors (5). One of these cytokines, EGF, also increases the HIF-1 $\alpha$ level by activating EGF receptor (EGFR) signaling in normoxic conditions. EGF-stimulated HIF-1 $\alpha$ expression is regulated by various signal transduction pathways, such as the phosphatidylinositol-3-kinase (PI3K)/Akt signaling pathway and the p38, c-Jun N-terminal protein kinase, and extracellular signal-regulated protein kinase (ERK), which all belong to the mitogen-activated protein kinase (MAPK) family signaling pathway $(14,15)$. It is widely known that EGF-induced phosphorylation of mammalian target of rapamycin (mTOR) leads to HIF-1 $\alpha$ protein synthesis through regulation of p70S6 kinase 1 (p70S6K) and eukaryotic initiation factor 4E-binding protein 1 (4E-BP1) (10).

Delphinidin, a polyphenol that belongs to the group of anthocyanidins, is abundant in many pigmented fruits (berries and dark grapes) and vegetables (eggplants and tomatoes). Delphinidin has anti-inflammatory, antioxidant, anti-proliferative, and antitumor activities in a variety of cancer cells $(16,17)$. It was recently reported to have inhibitory effects on angiogenesis (18) and to prevent hypoxia-induced activation of nuclear factor- $\kappa \mathrm{B}(\mathrm{NF}-\kappa \mathrm{B})$, and Akt inhibition (19). Delphinidin also decreases downstream signaling cascades crucial for endothelial cell tube formation through VEGFR-2 inhibition (20). However, there is no information concerning the molecular mechanisms underlying the VEGF-related anti-angiogenic effects of delphinidin in lung cancer cells.

In this study, we investigated the inhibitory effects of delphinidin on HIF- $1 \alpha$ and VEGF expression in human lung adenocarcinoma A549 cells. We found that delphinidin specifically inhibits EGF-induced VEGF expression by blocking HIF-1 $\alpha$ protein expression, without regulating HIF-1 $\alpha$ mRNA expression. Additionally, delphinidin appeared to reduce HIF-1 $\alpha$ protein synthesis by inhibiting the ERK and Akt/mTOR/p70S6K signaling pathways.

\section{Materials and methods}

Cell culture and materials. A549 (human lung adenocarcinoma cells), NCI-H460 (human lung adenocarcinoma cells, MCF-7 (human breast carcinoma cells), and PC3M (human prostate cancer cells) were obtained from the American Type Culture Collection (ATCC, Manassas, VA, USA). A549 cells were cultured in RPMI-1640 medium (Gibco, Grand Island,
NY, USA) supplemented with $10 \%$ fetal bovine serum (FBS) and incubated at $37^{\circ} \mathrm{C}$ in a humidified atmosphere containing $5 \% \mathrm{CO}_{2}$. Delphinidin was obtained from Cayman Chemical Co. (Ann Arbor, MI, USA).

Cell viability assay. Cells were plated in 96-well culture plates at a density of $1 \times 10^{4}$ cells/well in RPMI-1640 culture medium and allowed to attach for $24 \mathrm{~h}$. The media were then discarded and replaced with $100 \mu \mathrm{l}$ of new medium containing various concentrations of delphinidin and cultured for $24 \mathrm{~h}$. A WST-1 assay kit (Cayman Chemical Co.) was added to each well. The amount of formazan deposits was quantified according to the supplier's protocol after $4 \mathrm{~h}$ of incubation with WST-1 test solution at $37^{\circ} \mathrm{C}$ in a $5 \% \mathrm{CO}_{2}$ incubator.

Western blot analysis. A549 cells were pre-incubated for $24 \mathrm{~h}$, then stimulated with $\mathrm{CoCl}_{2}(200 \mu \mathrm{M})$ and EGF $(20 \mathrm{ng} / \mathrm{ml})$ in the presence of delphinidin. After incubation, the cells were collected and washed twice with cold PBS. The cells were lysed in a lysis buffer [50 mM Tris- $\mathrm{HCl}$ (pH 7.5), $150 \mathrm{mM}$ $\mathrm{NaCl}, 1 \%$ Nonidet P-40, 2 mM EDTA, 1 mM EGTA, $1 \mathrm{mM}$ $\mathrm{NaVO}_{3}, 10 \mathrm{mM} \mathrm{NaF}, 1 \mathrm{mM}$ dithiothreitol, $1 \mathrm{mM}$ phenylmethylsulfonyl fluoride, $25 \mu \mathrm{g} / \mathrm{ml}$ aprotinin, and $25 \mu \mathrm{g} / \mathrm{ml}$ leupeptin] and maintained on ice for $30 \mathrm{~min}$. The cell lysates were obtained via centrifugation, and the protein concentrations were determined using a protein assay kit. Aliquots of the lysates were separated on $12 \%$ SDS-polyacrylamide gel and transferred onto a nitrocellulose transfer membrane (Whatman, Dassel, Germany) with a glycine transfer buffer [192 mM glycine, 25 mM Tris- $\mathrm{HCl}$ (pH 8.8), 20\% methanol (v/v)]. After blocking the nonspecific site with $1 \%$ bovine serum albumin (BSA), the membrane was incubated overnight with a specific primary antibody at $4^{\circ} \mathrm{C}$. The membrane was then incubated for an additional $1 \mathrm{~h}$ with a peroxidaseconjugated secondary antibody $(1: 1,000$; Vector Laboratories, Inc., Burlingame, CA, USA) at room temperature. The immunoactive proteins were detected using an enhanced chemiluminescence (ECL) western blot analysis detection kit (Advansta, Inc., Menlo Park, CA, USA).

Reverse transcription-polymerase chain reaction (RT-PCR). Total RNA was extracted from cells using TRIzol reagent (Invitrogen, Carlsbad, CA, USA). Reverse transcription was carried out using a commercial kit (SuperScript II RNase $\mathrm{H}$-reverse transcriptase; Invitrogen) and total RNA (1 $\mu \mathrm{g})$ from A549 cells, according to the manufacturer's instructions. The sequences of the primers were as follows: for HIF-1 $\alpha, 5$ '-CTC AAAGTCGGACAGCCTCA-3' (sense) and 5'-AATGAGCCA CCAGTGTCCAA-3' (antisense); for VEGF, 5'-CTACCTCCAC CATGCCAAGT- 3' (sense) and 5'-TCTCTCCTATGTGCTG GCCT-3' (antisense); for $\beta$-actin, 5'-GCCATCGTCACCAACT GGGAC-3' (sense) and 5'-CGATTTCCCGCTCGGCCG TGG-3' (antisense). PCR products were visualized using $1 \%$ agarose gel electrophoresis with ethidium bromide staining.

Enzyme-linked immunosorbent assay (ELISA). Cells were plated in 6-well culture plates at $2 \times 10^{5}$ cells/well in RPMI-1640 culture medium and treated with various concentrations of delphinidin for $12 \mathrm{~h}$ in the presence of EGF. The VEGF levels in the culture supernatant were determined by ELISA 
using the VEGF ELISA development kit (R\&D Systems, Inc., Minneapolis, MN, USA) according to the manufacturer's instructions.

Luciferase reporter gene assay. The ability of delphinidin to inhibit HIF-1 $\alpha$ transcription was determined by the reporter gene assay dependent on the HRE. In brief, at $50-80 \%$ confluency, A549 cells were co-transfected with pGL3-HRE-luciferase, which contained six copies of HRE derived from the human VEGF gene, and pRL-CMV (Promega Corp., Madison, WI, USA), which encoded Renilla luciferase (Rluc) under the control of a constitutive promoter, using Lipofectamine Plus reagent (Invitrogen) according to the manufacturer's instructions.

Real-time polymerase chain reaction (PCR). Total RNA was extracted from the cells with TRIzol reagent (Invitrogen), and reverse-transcriptase reactions were performed with a commercial kit (SuperScript II RNase H-reverse transcriptase; Invitrogen) using $50 \mu \mathrm{g} / \mathrm{ml}$ RNA. Quantitative PCRs were conducted on a real-time PCR system (LightCycler; Roche Diagnostics, Basel, Switzerland) with a commercial kit (SYBR-Green with low ROX; Enzynomics, Daejeon, Korea) in a reaction mixture containing diluted cDNA (1/5) as a template and the real-time PCR primers. The sequences of the primers were as follows: for HIF-1 $\alpha$, 5'-CTCAAAGTCGGA CAGCCTCA-3' (sense) and 5'-AATGAGCCACCAGTGTC CAA-3' (antisense); for VEGF, 5'-CTACCTCCACCATGCCA AGT-3' (sense) and 5'-TCTCTCCTATGTGCTGGCCT-3' (antisense); for $\beta$-actin, 5'-ACAGGAAGTCCCTTGCCATC-3' (sense) and 5'-AGGGAGACCAAAAGCCTTCA-3' (antisense). The relative mRNA expression levels were normalized to the value of $\beta$-actin for each reaction.

Matrigel plug assay. C57BL/6N mice (male, 6 weeks) were purchased from Samtako (Osan, Korea) and maintained in pathogen-free conditions. A549 cells at subconfluence were harvested, washed with PBS, and re-suspended in serum-free medium. Aliquots of cells $\left(3 \times 10^{6}\right)$ were mixed with $0.5 \mathrm{ml}$ of Matrigel in the presence or absence of EGF (200 ng/ml) and delphinidin. Immediately, the mixture was subcutaneously injected into mice. The mice were sacrificed when tumors were visible, and the Matrigel plugs were carefully separated from adjacent tissue and photographed.

Hemoglobin concentration measurement. The separated Matrigel plugs were excised, and then were placed in cold PBS at $4^{\circ} \mathrm{C}$ overnight to liquefy the Matrigel. Specimens were subjected to centrifugation at $14,000 \mathrm{rpm}$ and the supernatants were collected. The hemoglobin content was determined using Drabkin's reagent kit (Sigma Chemical Co., St. Louis, MO, USA), as previously described (21). All surgical and experimental procedures used in this study were approved by the Institutional Review Board Committee at Daegu Catholic University Medical Center which conforms to the US National Institutes of Health Guidelines for the Care and Use of Laboratory Animals.

Statistical analysis. All results are representative of at least three independent experiments performed in triplicate. The statistical significance between experimental and control values was calculated using a one-way ANOVA test.

\section{Results}

Delphinidin inhibits $\mathrm{CoCl}_{2}$ - and EGF-induced HIF-1 expression in various cancer cells. HIF-1 is a master regulator of numerous genes involved in cell survival, adaptation to hypoxia, metabolism, and angiogenesis (22). Before investigating the inhibitory potential of delphinidin (Fig. 1A), the cytotoxic effects of delphinidin were examined by the WST-1 assay. Delphinidin did not significantly affect the viability of A549 or NCI-H460 lung cancer cells at the indicated concentrations (Fig. 1B). Delphinidin did not show any cytotoxic effects at concentrations of up to $40 \mu \mathrm{M}$; therefore, 10,20 and $40 \mu \mathrm{M}$ delphinidin was used in the subsequent experiments. To determine if delphinidin inhibits HIF-1 $\alpha$ expression, we investigated the HIF- $1 \alpha$ and HIF-1 $\beta$ protein levels under various conditions using western blot analysis. $\mathrm{CoCl}_{2}(200 \mu \mathrm{M})$ and EGF $(20 \mathrm{ng} / \mathrm{ml})$ treatment greatly induced HIF-1 $\alpha$ protein expression levels in the various cancer cells. Delphinidin dose-dependently decreased $\mathrm{CoCl}_{2}$-stimulated HIF-1 $\alpha$ protein expression in the A549 (lung carcinoma), NCI-H460 (lung carcinoma), MCF-7 (breast carcinoma), and PC3M (prostate cancer) cells. In particular, at a concentration of $40 \mu \mathrm{M}$, delphinidin completely abrogated HIF-1 $\alpha$ protein expression. However, $\mathrm{CoCl}_{2}$ and delphinidin did not affect HIF-1 $\beta$ protein expression (Fig. 1C). Under the EGF-induced conditions, delphinidin decreased HIF-1 $\alpha$ protein expression without affecting HIF- $1 \beta$ protein expression (Fig. 1D). As the inhibitory effects of delphinidin on $\mathrm{CoCl}_{2}$ - and EGF-stimulated HIF-1 $\alpha$ protein expression in A549 cells was higher than that in the other cell lines, A549 cells were used in the subsequent experiments.

Delphinidin inhibits $\mathrm{CoCl}_{2^{-}}$and EGF-induced VEGF transcription levels and HRE promoter activity. VEGF, the main target gene of HIF-1 $\alpha$, directly participates in angiogenesis (23). To determine if the decrease in HIF-1 $\alpha$ expression by delphinidin affects VEGF expression, the VEGF mRNA levels were evaluated using RT-PCR. Delphinidin dose-dependently decreased the VEGF mRNA levels under the $\mathrm{CoCl}_{2}$ - and EGF-stimulated conditions (Fig. 2A). Moreover, treatment with $40 \mu \mathrm{M}$ delphinidin dramatically reduced the VEGF mRNA levels in both conditions.

Next, we examined the effects of delphinidin on the secretion of the VEGF protein in $\mathrm{CoCl}_{2}$ - and EGF-stimulated conditions via ELISA assay. Secretion of VEGF protein was significantly increased by up to 2-fold in cells treated with $\mathrm{CoCl}_{2}$ or EGF compared with untreated cells (Fig. 2B). Delphinidin treatment dose-dependently decreased the secretion of VEGF protein in the $\mathrm{CoCl}_{2}$ - and EGF-stimulated A549 cells. Because delphinidin inhibited HIF-1 $\alpha$ protein expression in various cancer cells, we sought to confirm that delphinidin regulated VEGF secretion in the other cancer cell lines. In MCF-7 and PC3M cells, $\mathrm{CoCl}_{2}$ - and EGF-stimulated VEGF protein secretion was also decreased by delphinidin in a dosedependent manner (Fig. 2C). Although non-treated H460 cells secreted high levels of VEGF protein, treatment with $40 \mu \mathrm{M}$ delphinidin decreased $\mathrm{CoCl}_{2}$ - and EGF-induced VEGF protein secretion levels when compared with the non-treated H460 
A<smiles>Oc1cc(O)c2cc(O)c(-c3cc(O)c(O)c(O)c3)[o+]c2c1</smiles>

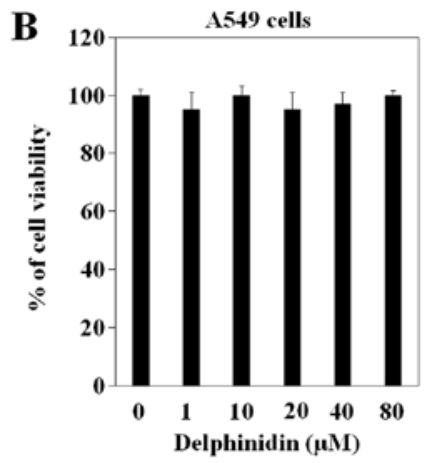

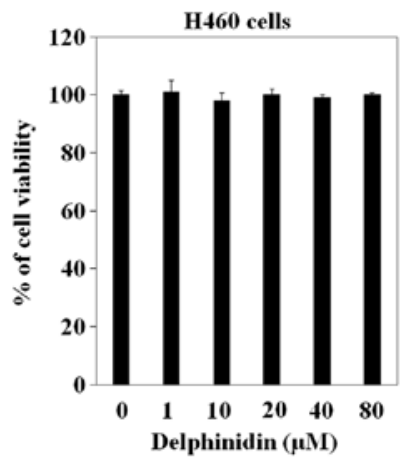

D

D EGF (20 ng/ml) $\begin{array}{llllll}\text { Delphinidin }(\mu \mathrm{M}) & 0 & 0 & 10 & 20 & 40\end{array}$

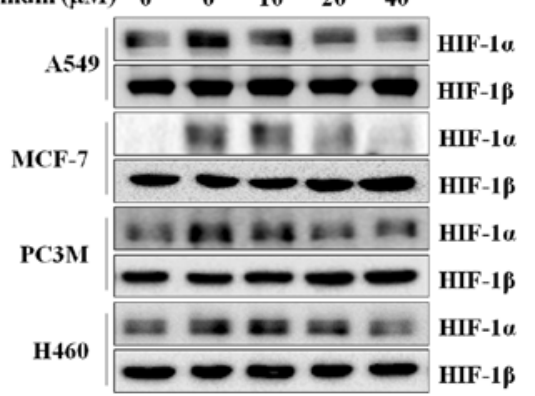

Figure 1. Inhibitory effects of delphinidin on hypoxia-inducible factor (HIF)-1 $\alpha$ expression. (A) Chemical structure of delphinidin. (B) A549 and H460 cells were treated with the indicated concentrations of dephinidin for $24 \mathrm{~h}$. Cell viability was determined by a WST-1 assay. The data represent the means \pm SE of three separate experiments. (C and D) The indicated cancer cell lines were pretreated with delphinidin for $1 \mathrm{~h}$, and then induced by CoCl $\mathrm{C}_{2}$ or epidermal growth factor (EGF) treatment for $6 \mathrm{~h}$. The nuclear extracts were subjected to western blot analysis using antibodies against HIF-1 $\alpha$ and HIF-1 $\beta$.

A

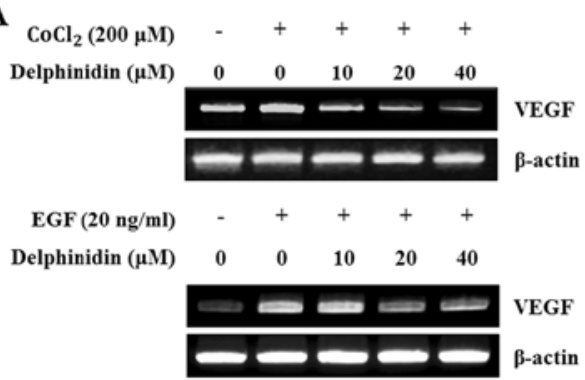

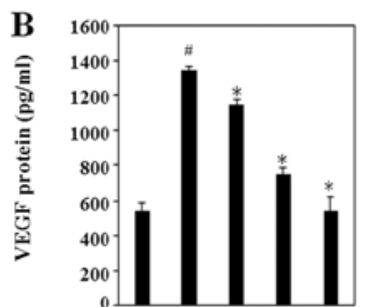

$\mathrm{CoCl}_{2}(200 \mu \mathrm{M})$ Delphinidin $(\mu \mathrm{M})-0$

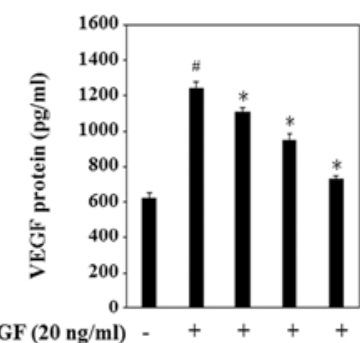

EGF $(20 \mathrm{ng} / \mathrm{ml})$

Delphinidin $(\mu \mathrm{M}) \quad 0 \quad 0 \quad 10 \quad 20 \quad 40$

\section{C}

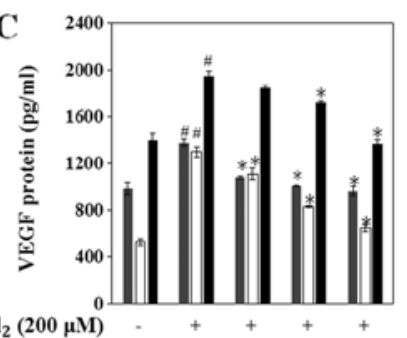

$\mathrm{CoCl}_{2}(200 \mu \mathrm{M})$

Delphinidin $(\mu \mathrm{M})$
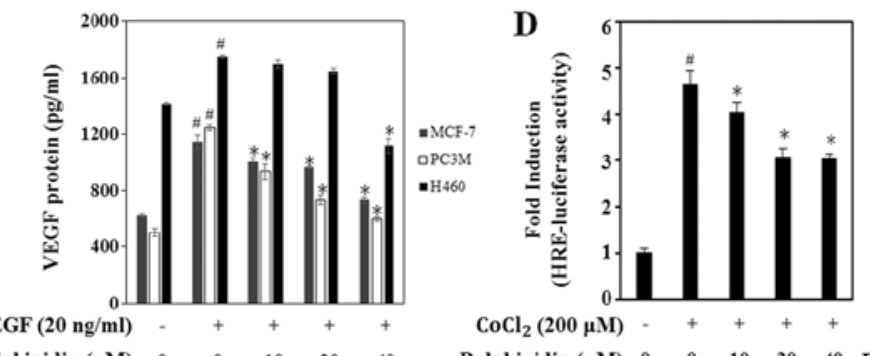

$\mathrm{CoCl}_{2}(200 \mu \mathrm{M})$

Figure 2. Inhibitory effects of delphinidin on $\mathrm{CoCl}_{2}$ - and epidermal growth factor (EGF)-induced vascular endothelial growth factor (VEGF) expression. (A) RT-PCR analysis of VEGF mRNA was carried out using total RNA prepared from A549 cells incubated with $\mathrm{CoCl}_{2}$ or EGF treatments for $12 \mathrm{~h}$ in the presence of the indicated concentrations of delphinidin. (B and C) VEGF protein expression was evaluated by ELISA in culture supernatant of cells after incubation with $\mathrm{CoCl}_{2}$ or EGF treatment in the presence or absence of the indicated concentrations of delphinidin. (D) A549 cells were transiently co-transfected with a reporter gene, pGL3-HRE-Luciferase, and pRL-CMV as a reference. Following incubation for $24 \mathrm{~h}$, the cells were incubated with CoCl ${ }_{2}$ or EGF treatment in the presence or absence of the indicated concentration of delphinidin for $12 \mathrm{~h}$. The data represent the means \pm SD of three independent experiments $\left({ }^{*} \mathrm{p}<0.05\right.$ as compared to control; ${ }^{*} \mathrm{p}<0.05$ as compared to $\mathrm{CoCl}_{2}$ and EGF-treated control).

cells. These results suggest that the inhibitory effect of delphinidin on VEGF protein production is regulated by decreasing the VEGF mRNA level in $\mathrm{CoCl}_{2}$ - and EGF-stimulated conditions in various cell lines. 
$\mathbf{A}$
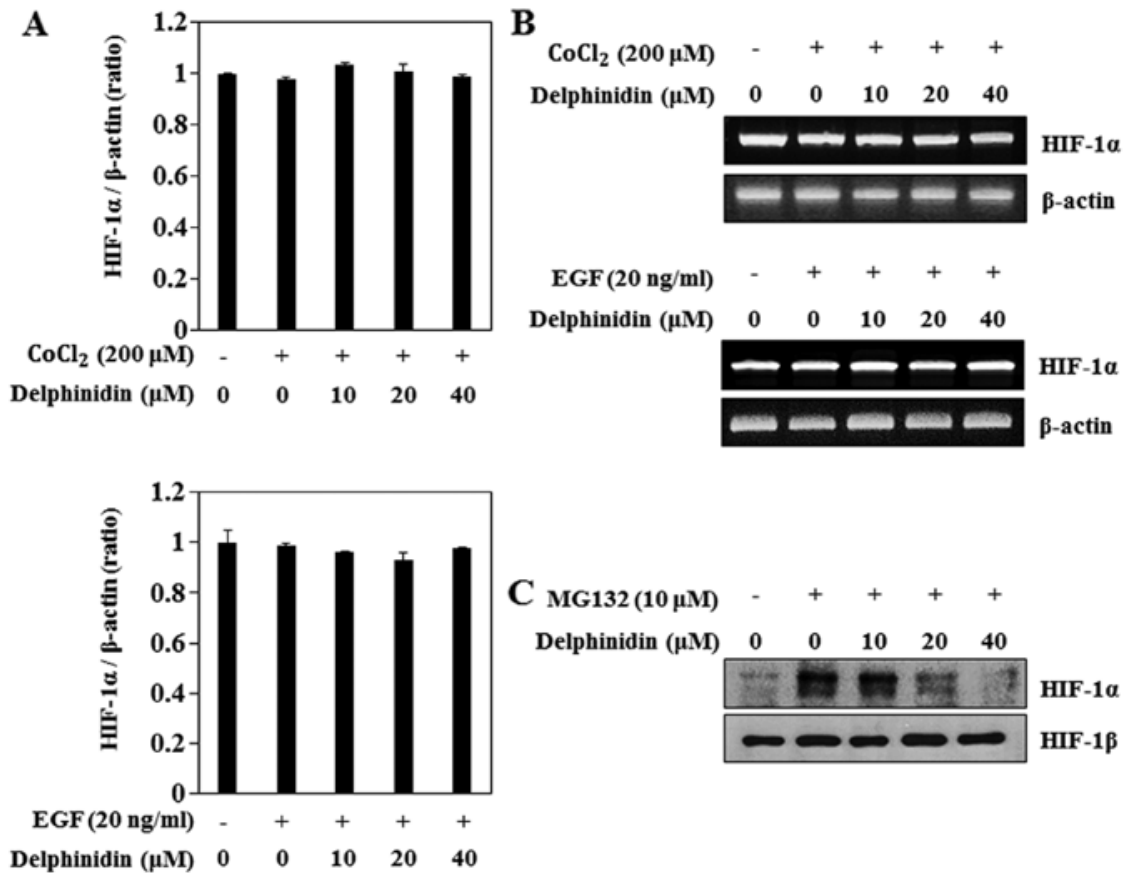

Figure 3. Inhibitory effects of delphinidin on hypoxia-inducible factor (HIF)-1 $\alpha$ mRNA expression in A549 cells. (A) A549 cells were treated with delphinidin for $24 \mathrm{~h}$. Relative mRNA for HIF- $1 \alpha$ after normalization with $\beta$-actin expression determined by quantitative PCR is shown. The data represent the means \pm SD of three independent experiments. (B) RT-PCR analysis of HIF-1 $\alpha$ mRNA was carried out using total RNA. A549 cells incubated with CoCl ${ }_{2}$ or EGF treatments for $12 \mathrm{~h}$ in the presence of the indicated concentrations of delphinidin. (C) A549 cells were pretreated with delphinidin, for $1 \mathrm{~h}$, and then induced by MG132 treatment for $6 \mathrm{~h}$. The nuclear extracts were subjected to western blot analysis using antibodies against HIF-1 $\alpha$ and HIF-1 $\beta$.

The binding of HIF-1 to HRE in the VEGF promoter is a predominant enhancer of VEGF production (13). Thus, to investigate if delphinidin suppresses HRE promoter activity by decreasing HIF-1 $\alpha$ protein expression, we performed an HRE promoter reporter gene assay. A549 cells were co-transfected with the pGL3-HRE-luciferase and $\beta$-galactosidase-luciferase plasmids for $24 \mathrm{~h}$ and then treated with the indicated concentration of delphinidin for $12 \mathrm{~h}$. HRE promoter activity was increased up to 4.5 -fold in the $\mathrm{CoCl}_{2}$-stimulated cells compared with the untreated cells (Fig. 2D). Delphinidin dose-dependently decreased $\mathrm{CoCl}_{2}$-stimulated HRE promoter activity. In addition, EGF-induced HRE promoter activity was increased up to $\sim 5$-fold compared with the untreated cells and was rapidly decreased after treatment with $10 \mu \mathrm{M}$ delphinidin. These results showed that the inhibitory effects of delphinidin on VEGF transcriptional activity are related to the regulation of HRE promoter activity by inhibiting HIF-1 $\alpha$ expression.

The inhibitory effects of delphinidin on $\mathrm{CoCl}_{2}$ and EGF-induced HIF-1 $\alpha$ expression are not related to transcriptional levels. To determine if delphinidin decreased HIF-1 $\alpha$ protein expression by regulating the HIF- $1 \alpha$ mRNA levels, we examined the effects of delphinidin on $\mathrm{CoCl}_{2}$ - and EGF-induced HIF- $1 \alpha$ transcriptional activity using real-time PCR. $\mathrm{CoCl}_{2}$ and EGF treatment did not induce HIF-1 $\alpha$ mRNA levels (Fig. 3A). Furthermore, delphinidin treatment did not change the HIF- $1 \alpha$ mRNA level in $\mathrm{CoCl}_{2}$ - or EGF-stimulated A549 cells. In addition, the results of the RT-PCR assay showed that delphinidin did not affect the HIF-1 $\alpha$ mRNA levels (Fig. 3B). These results showed that HIF-1 $\alpha$ mRNA levels were not responsible for the inhibition of HIF-1 $\alpha$ protein expression by delphinidin in the $\mathrm{CoCl}_{2}$ - and EGF-induced conditions. Next, to determine the effect of delphinidin on HIF-1 $\alpha$ protein proteasomal degradation, proteasome inhibitor MG132 was used. MG132 significantly increased HIF-1 $\alpha$ protein accumulation (Fig. 3C). Delphinidin also inhibited MG132-induced HIF-1 $\alpha$, which suggests that delphinidin did not appear to affect the proteasomal degradation of the HIF-1 $\alpha$ protein. Therefore, we anticipated that the inhibitory effects of delphinidin on $\mathrm{CoCl}_{2}$ - and EGF-induced HIF-1 $\alpha$ protein expression are regulated by a synthesis pathway.

Delphinidin inhibits $\mathrm{CoCl}_{2-}$ and EGF-induced HIF-1a expression by blocking the ERK and PI3K/Akt/mTOR/p70S6K signaling pathways in A549 cells. The MAPK and Akt/mTOR pathways are associated with the regulation of HIF-1 $\alpha$ protein synthesis at the translational levels $(24,25)$. Thus, to confirm that MAPK, Akt, and mTOR pathway activity is related to $\mathrm{CoCl}_{2}$ - and EGF-induced HIF-1 $\alpha$ protein expression, A549 cells were exposed to various kinase inhibitors. PD98059 (a MEK inhibitor), wortmannin (a PI3K inhibitor), and rapamycin (an mTOR inhibitor) blocked $\mathrm{CoCl}_{2}$-induced HIF-1 $\alpha$ expression, similarly to delphinidin (Fig. 4A). By contrast, SB203589 (a p38 inhibitor) did not affect HIF-1 $\alpha$ protein expression in A549 cells. In EGF-stimulated cells PD98059, wortmannin, and rapamycin also blocked HIF-1 $\alpha$ expression (Fig. 4B). These results indicate that $\mathrm{CoCl}_{2}$ - and EGF-induced HIF-1 $\alpha$ protein expression is regulated by the ERK, PI3K and mTOR pathways, whereas the p38-mediated pathways are not involved.

To determine the mechanisms underlying HIF- $1 \alpha$ inhibition by delphinidin, the phosphorylated forms of ERK, PI3K, Akt and mTOR were detected via western blot analysis. The phosphorylation of ERK, PI3K, Akt, mTOR and p70S6K were increased at $10 \mathrm{~min}$ after $\mathrm{CoCl}_{2}$ - and EGF-treatment, while 
A
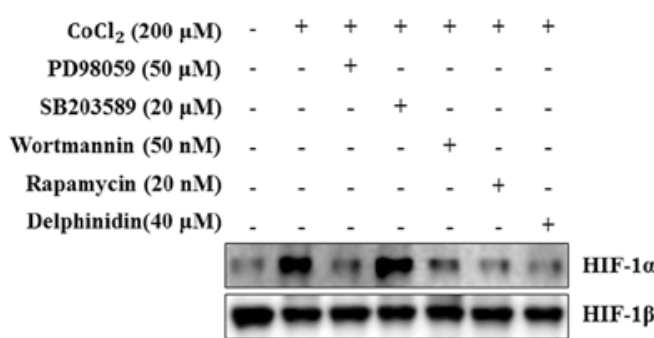

B

$\begin{array}{rlllllll}\text { EGF }(20 \mathrm{ng} / \mathrm{ml}) & - & + & + & + & + & + & + \\ \text { PD98059 }(50 \mu \mathrm{M}) & - & - & + & - & - & - & - \\ \text { SB203589 }(20 \mu \mathrm{M}) & - & - & - & + & - & - & - \\ \text { Wortmannin }(50 \mathrm{nM}) & - & - & - & - & + & - & - \\ \text { Rapamycin }(20 \mathrm{nM}) & - & - & - & - & - & + & - \\ \text { Delphinidin }(40 \mu \mathrm{M}) & & & & & & & \end{array}$

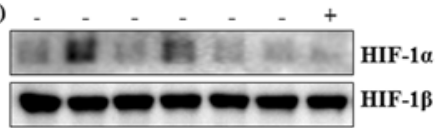

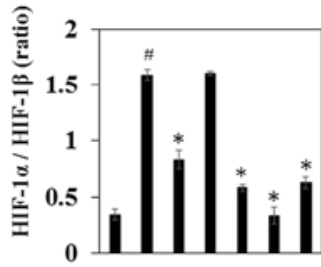

$\mathrm{CoCl}_{2}(200 \mu \mathrm{M})$

\section{PD98059 (50 $\mu \mathrm{M})$}

SB203589 $(20 \mu \mathrm{M})$

Wortmannin $(50 \mathrm{nM})$

Rapamycin (20 nM)

Delphinidin $(40 \mu \mathrm{M})$

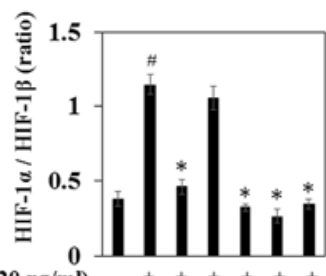

EGF $(20 \mathrm{ng} / \mathrm{ml})$

PD98059 (50 $\mu \mathrm{M})$

SB203589 $(20 \mu \mathrm{M})$

Wortmannin $(50 \mathrm{nM})$

Rapamycin (20 nM)

Delphinidin $(40 \mu \mathrm{M})$

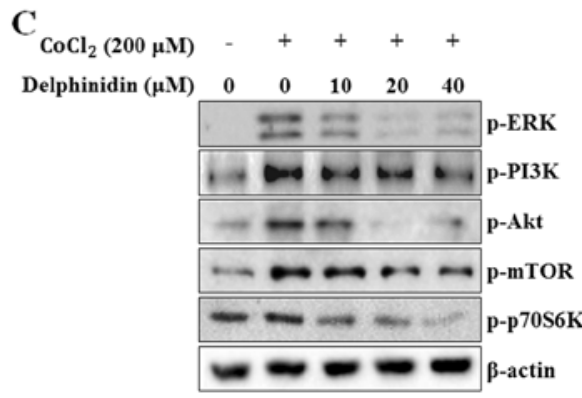

$\mathrm{D}$

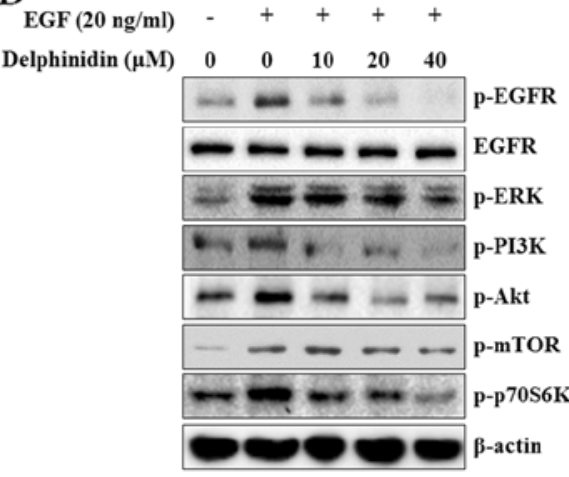

Figure 4. Inhibitory effects of delphinidin on $\mathrm{CoCl}_{2}$ - or epidermal growth factor (EGF)-induced phosphorylation of EGFR, extracellular signal-regulated protein kinase (ERK), phosphatidylinositol-3-kinase (PI3K), Akt, mammalian target of rapamycin (mTOR), and p70S6 kinase (p70S6K) in A549 cells. (A and B) A549 cells were pretreated with delphinidin, PD98059, SB203589, wortmannin, or rapamycin for 30 min, and then induced by CoCl ${ }_{2}$ or EGF treatment for $6 \mathrm{~h}$. The nuclear extracts were subjected to western blot analysis using antibodies against HIF-1 $\alpha$ or HIF-1 $\beta$. (C and D) A549 cells were pretreated with the indicated concentrations of delphinidin for $1 \mathrm{~h}$, followed by incubation with $\mathrm{CoCl}_{2}$ or EGF for $10 \mathrm{~min}$. The phosphorylated levels of EGFR, ERK, PI3K, Akt, mTOR, and p70S6K were determined by western blot analysis.

A

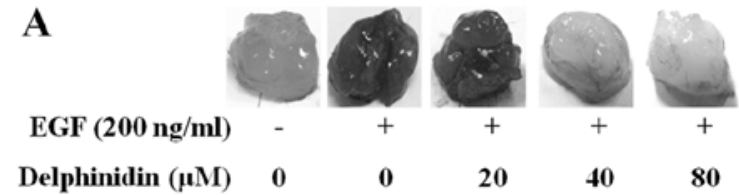

B

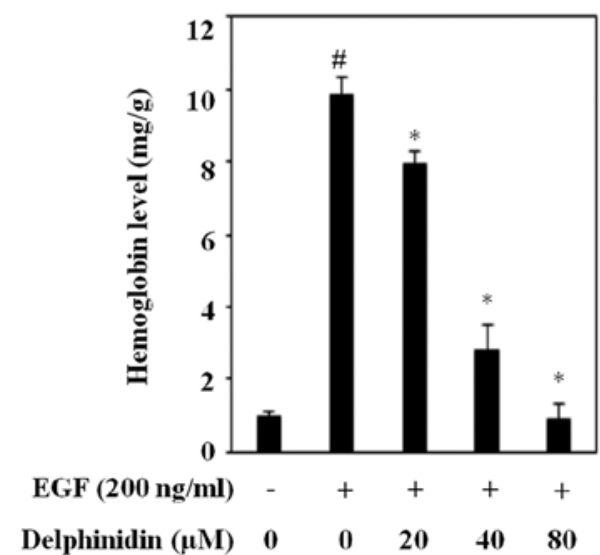

Figure 5. Inhibitory effects of delphinidin on tumor angiogenesis in vivo. (A) $57 \mathrm{BL} / 6 \mathrm{~N}$ mice were subcutaneously injected with Matrigel $(500 \mu 1)$ and A549 cell $\left(3 \times 10^{6}\right)$ mixture with the indicated drugs. The mice were euthanized 7 days after implantation, and the Matrigel plugs were removed and photographed. (B) The amounts of hemoglobin in the Matrigel plugs were quantified using a Drabkin agent. The data represent the means \pm SD of three independent experiments ( ${ }^{\#} \mathrm{p}<0.05$ as compared to the control; ${ }^{*} \mathrm{p}<0.05$ as compared to the EGF treatment). delphinidin reduced phosphorylation of ERK, PI3K, Akt, mTOR, and p70S6K in $\mathrm{CoCl}_{2}$-stimulated A549 cells (Fig. 4C and D). Similarly, delphinidin dose-dependently inhibited EGF-induced phosphorylation of ERK, PI3K, Akt, mTOR, and p70S6K. Phosphorylation of tyrosine residue $1068\left(\mathrm{Tyr}^{1068}\right)$ of EGFR is part of the initial activation process and these phosphotyrosine residues subsequently serve as docking sites for intracellular signaling molecules (26). Thus, to determine if the inhibition of HIF-1 $\alpha$ protein synthesis was mediated by the downregulation of the EGFR tyrosine residue, the effect of delphinidin on the phosphorylation of EGFR $\left(\mathrm{Tyr}^{1068}\right)$ was determined. The results showed that delphinidin inhibited EGF-induced EGFR phosphorylation. These results suggest that delphinidin suppresses HIF- $1 \alpha$ protein synthesis by the inhibiting EGFR-dependent and -independent activation of the ERK and PI3K/Akt/mTOR/p70S6K signaling pathways.

Delphinidin inhibits tumor angiogenesis in vivo. To further determine if delphinidin inhibits angiogenesis by blocking the expression of HIF-1 $\alpha$ and VEGF, we performed a Matrigel plug assay in vivo. Matrigel plugs mixed with only cancer cells did not induce blood vessel formation. New blood vessel formation was induced by EGF-treated cancer cells (Fig. 5A). Delphinidin considerably suppressed EGF-induced angiogenesis, and it was almost completely abrogated upon treatment with $80 \mu \mathrm{M}$ delphinidin. Moreover, delphinidin dose-dependently reduced the EGF-increased hemoglobin content (Fig. 5B). These results indicate that delphinidin is an 
angiogenesis inhibitor and an antitumor therapeutic agent in human lung adenocarcinoma A549 cells.

\section{Discussion}

Natural dietary polyphenolic compounds prevent cancer due to their multitude of biological activities (27). Delphinidin, a polyphenol that belongs to the group of anthocyanidins, has potent antioxidant, anti-proliferative, and anti-angiogenic properties in various cells (28). It was reported that delphinidin exerts an inhibitory effect on angiogenesis (18). It also inhibits endothelial cell proliferation and cell cycle progression through transient activation of ERK1/2 (16). However, there is no information about its ability to regulate angiogenesis via HIF-1 $\alpha$-dependent signaling pathways.

Tumor cells promote angiogenesis through an oxygen-sensing mechanism by regulating angiogenic and anti-angiogenic factors under hypoxic conditions (29). Cellular adaptation to hypoxia is associated with several transcriptional factors, such as activator protein $-1, \mathrm{NF}-\kappa \mathrm{B}$, and HIF-1 (3). Among the transcriptional factors, activation of HIF-1, which is composed of the HIF- $1 \alpha$ and HIF- $1 \beta$ subunits, increases cell proliferation and invasion in cancers, such as lung and prostate cancer $(30,31)$. HIF-1 $\alpha$ expression is regulated not only by hypoxia but also by ions. Among ions, $\mathrm{CoCl}_{2}$ has been used both in vivo (32) and in vitro (33) to mimic hypoxic conditions (33). It stabilizes HIF-1 $\alpha$ by inhibiting HIF-1 $\alpha$-specific prolyl hydroxylase, leading to the impaired binding of the VHL protein to HIF-1 $\alpha$ and prevention of its proteasomal degradation $(34,35)$. In addition, HIF-1 $\alpha$ expression is regulated by EGF, which increases HIF-1 $\alpha$ translation by stimulating EGFR in normoxia. Therefore, we investigated the inhibitory effects of delphinidin on HIF- $1 \alpha$ and VEGF expression in EGF- and $\mathrm{CoCl}_{2}$-stimulated lung cancer cells.

HIF-1 $\alpha$ protein expression was effectively increased in the $\mathrm{CoCl}_{2}$ - and EGF-induced conditions. Delphinidin markedly decreased the stimulated HIF-1 $\alpha$ protein expression without having toxic effects on lung cancer cells (Fig. 1). Previous studies reported that treatment with delphinidin for $24 \mathrm{~h}$ does not have cytotoxic effects on lung cancer cells or normal cells $(17,36)$, suggesting that the inhibitory effects of delphinidin on HIF-1 $\alpha$ protein expression are not related to cell cytotoxicity. To investigate the possible pathway by which delphinidin inhibits HIF-1 $\alpha$ expression, we evaluated the effect of delphinidin on the phosphorylation of various kinases. HIF-1 $\alpha$ protein synthesis is induced by EGF-induced PI3K/Akt and mTOR signaling pathways (15). mTOR controls the translation of various genes, by regulating two important downstream substrates, p70S6K and 4E-BP1 $(37,38)$. Phosphorylation of p70S6K induces HIF-1 $\alpha$ protein synthesis by controlling HIF-1 $\alpha$ mRNA translation within the 5 untranslated region (39). In addition, ERK1 directly phosphorylates the carboxy-terminal domain of HIF-1 $\alpha$ in hypoxia conditions (40). Therefore, to confirm the mechanism involved in the HIF-1 $\alpha$ regulation by delphinidin, we used the inhibitors of MAPK, PI3K and mTOR. Similar to the effect of delphinidin, PD98059, wortmannin, and rapamycin decreased both the $\mathrm{CoCl}_{2}$ - and EGF-induced HIF-1 $\alpha$ protein expressions. On the other hand, the treatment of the cells with SB203589 did not change the HIF- $1 \alpha$ protein expression in the $\mathrm{CoCl}_{2}$-stimulated condition. In the EGF-stimulated condition, only SB203589 did not influence HIF-1 $\alpha$ protein expression (Fig. 4). These findings indicate that the $\mathrm{CoCl}_{2}$ - and EGF-induced HIF-1 $\alpha$ protein expression levels were regulated through the ERK, Akt, and mTOR signaling pathways. In addition, we found that delphinidin inhibits the phosphorylation of ERK, PI3K, Akt, mTOR, and p70S6K. These results corresponded with the previous findings that delphinidin inhibits HER2 and ERK1/2 signaling with growth inhibition and apoptosis in breast cancer cells (41) and that delphinidin inhibits EGF-induced activation of PI3K and phosphorylation of Akt at $\operatorname{Ser}^{473}$ (28). In addition, delphinidin decreased EGF-induced EGFR phosphorylation at $\mathrm{Tyr}^{1068}$. EGFR phosphorylation $\left(\mathrm{Tyr}^{1068}\right)$ generates a motif for Grb2/SH2 domain binding, which initiates ERK activation (26), suggesting that delphinidin suppresses EGF-induced ERK by inhibiting EGFR phosphorylation. However, because delphinidin decreased $\mathrm{CoCl}_{2}$ - as well as EGF-induced HIF-1 $\alpha$ protein expression, regulation of the ERK, PI3K, Akt, mTOR, and p70S6K signaling pathways plays a major role in the inhibitory effect of delphinidin on HIF-1 $\alpha$ protein synthesis.

VEGF is a major mediator of angiogenesis, which induces tumor growth, metastasis, and invasion by delivering oxygen and nutrients to cancer cells (42). As expected, delphinidin significantly decreased both $\mathrm{CoCl}_{2}$ - and EGF-induced VEGF mRNA expression and VEGF secretion and dose-dependently decreased $\mathrm{CoCl}_{2}$ - and EGF-induced HRE promoter activity (Fig. 2). Additionally, delphinidin markedly suppressed EGF-stimulated new blood vessel formation. These results suggest that delphinidin can be clinically used as an angiogenesis inhibitor in cancer therapy.

In conclusion, this study found for the first time that delphinidin suppresses HIF-1 $\alpha$ protein expression. The inhibitory effects of delphinidin on VEGF transcriptional activity and tumor angiogenesis may be related to HIF-1 $\alpha$ protein synthesis by suppression of the ERK, mTOR, and p70S6K pathways in both the $\mathrm{CoCl}_{2}$ - and EGF-induced conditions. Therefore, this study demonstrated that delphinidin may be useful as a new anti-angiogenic agent in lung cancer.

\section{Acknowledgements}

This study was supported by a grant of Xavier, Catholic University of Daegu (2015).

\section{References}

1. Xu X, Mao W, Chen Q, Zhuang Q, Wang L, Dai J, Wang H and Huang Z: Endostar, a modified recombinant human endostatin, suppresses angiogenesis through inhibition of $\mathrm{Wnt} / \beta$-catenin signaling pathway. PLoS One 9: e107463, 2014.

2. Shin JM, Jeong YJ, Cho HJ, Park KK, Chung IK, Lee IK, Kwak JY, Chang HW, Kim CH, Moon SK, et al: Melittin suppresses HIF-1 $\alpha /$ VEGF expression through inhibition of ERK and mTOR/p70S6K pathway in human cervical carcinoma cells. PLoS One 8: e69380, 2013.

3. Jeong JH, Jeong YJ, Cho HJ, Shin JM, Kang JH, Park KK, Park YY, Chung IK, Chang HW, Magae J, et al: Ascochlorin inhibits growth factor-induced HIF-1 $\alpha$ activation and tumor-angiogenesis through the suppression of EGFR/ERK/p70S6K signaling pathway in human cervical carcinoma cells. J Cell Biochem 113: 1302-1313, 2012

4. De S, Chen J, Narizhneva NV, Heston W, Brainard J, Sage EH and Byzova TV: Molecular pathway for cancer metastasis to bone. J Biol Chem 278: 39044-39050, 2003. 
5. Jeong YJ, Cho HJ, Magae J, Lee IK, Park KG and Chang YC: Ascofuranone suppresses EGF-induced HIF-1 $\alpha$ protein synthesis by inhibition of the $\mathrm{Akt} / \mathrm{mTOR} / \mathrm{p} 70 \mathrm{~S} 6 \mathrm{~K}$ pathway in MDA-MB-231 breast cancer cells. Toxicol Appl Pharmacol 273: 542-550, 2013.

6. Hosseini H, Rajabibazl M, Ebrahimizadeh W and Dehbidi GR: Inhibiting angiogenesis with human single-chain variable fragment antibody targeting VEGF. Microvasc Res 97: 13-18, 2014.

7. Ferrara $\mathrm{N}$ and Davis-Smyth T: The biology of vascular endothelial growth factor. Endocr Rev 18: 4-25, 1997.

8. Ferrara N, Gerber HP and LeCouter J: The biology of VEGF and its receptors. Nat Med 9: 669-676, 2003.

9. Boddy JL, Fox SB, Han C, Campo L, Turley H, Kanga S, Malone PR and Harris AL: The androgen receptor is significantly associated with vascular endothelial growth factor and hypoxia sensing via hypoxia-inducible factors HIF-1a, HIF-2a, and the prolyl hydroxylases in human prostate cancer. Clin Cancer Res 11: 7658-7663, 2005.

10. Semenza GL: Targeting HIF-1 for cancer therapy. Nat Rev Cancer 3: 721-732, 2003.

11. Ren W, Mi D, Yang K, Cao N, Tian J, Li Z and Ma B: The expression of hypoxia-inducible factor- $1 \alpha$ and its clinical significance in lung cancer: A systematic review and meta-analysis. Swiss Med Wkly 143: w13855, 2013.

12. Soggia A, Ramond C, Akiyama H, Scharfmann R and Duvillie B: von Hippel-Lindau gene disruption in mouse pancreatic progenitors and its consequences on endocrine differentiation in vivo: Importance of HIF1- $\alpha$ and VEGF-A upregulation. Diabetologia 57: 2348-2356, 2014.

13. Wu Y, Lucia K, Lange M, Kuhlen D, Stalla GK and Renner U: Hypoxia inducible factor-1 is involved in growth factor, glucocorticoid and hypoxia mediated regulation of vascular endothelial growth factor-A in human meningiomas. J Neurooncol 119: 263-273, 2014

14. Fan B, Wang YX, Yao T and Zhu YC: p38 Mitogen-activated protein kinase mediates hypoxia-induced vascular endothelial growth factor release in human endothelial cells. Sheng Li Xue Bao 57: 13-20, 2005

15. Déry MA, Michaud MD and Richard DE: Hypoxia-inducible factor 1: Regulation by hypoxic and non-hypoxic activators. Int J Biochem Cell Biol 37: 535-540, 2005.

16. Martin S, Favot L, Matz R, Lugnier C and Andriantsitohaina R: Delphinidin inhibits endothelial cell proliferation and cell cycle progression through a transient activation of ERK-1/-2. Biochem Pharmacol 65: 669-675, 2003.

17. Pal HC, Sharma S, Strickland LR, Agarwal J, Athar M, Elmets CA and Afaq F: Delphinidin reduces cell proliferation and induces apoptosis of non-small-cell lung cancer cells by targeting EGFR/VEGFR2 signaling pathways. PLoS One 8: e77270, 2013

18. Favot L, Martin S, Keravis T, Andriantsitohaina R and Lugnier C: Involvement of cyclin-dependent pathway in the inhibitory effect of delphinidin on angiogenesis. Cardiovasc Res 59: 479-487, 2003.

19. Seo BN, Ryu JM, Yun SP, Jeon JH, Park SS, Oh KB, Park JK and Han HJ: Delphinidin prevents hypoxia-induced mouse embryonic stem cell apoptosis through reduction of intracellular reactive oxygen species-mediated activation of JNK and NF- $\kappa \mathrm{B}$, and Akt inhibition. Apoptosis 18: 811-824, 2013.

20. Lamy S, Blanchette M, Michaud-Levesque J, Lafleur R, Durocher Y, Moghrabi A, Barrette S, Gingras D and Béliveau R: Delphinidin, a dietary anthocyanidin, inhibits vascular endothelial growth factor receptor-2 phosphorylation. Carcinogenesis 27: 989-996, 2006.

21. Passaniti A, Taylor RM, Pili R, Guo Y, Long PV, Haney JA, Pauly RR, Grant DS and Martin GR: A simple, quantitative method for assessing angiogenesis and antiangiogenic agents using reconstituted basement membrane, heparin, and fibroblast growth factor. Lab Invest 67: 519-528, 1992.

22. Ahn GO, Seita J, Hong BJ, Kim YE, Bok S, Lee CJ, Kim KS, Lee JC, Leeper NJ, Cooke JP, et al: Transcriptional activation of hypoxia-inducible factor-1 (HIF-1) in myeloid cells promotes angiogenesis through VEGF and S100A8. Proc Natl Acad Sci USA 111: 2698-2703, 2014
23. Ke Q and Costa M: Hypoxia-inducible factor-1 (HIF-1). Mol Pharmacol 70: 1469-1480, 2006.

24. Liu C, Shi Y, Du Y, Ning X, Liu N, Huang D, Liang J, Xue Y and Fan D: Dual-specificity phosphatase DUSP1 protects overactivation of hypoxia-inducible factor 1 through inactivating ERK MAPK. Exp Cell Res 309: 410-418, 2005.

25. Semenza G: Signal transduction to hypoxia-inducible factor 1 . Biochem Pharmacol 64: 993-998, 2002.

26. Rojas M, Yao S and Lin YZ: Controlling epidermal growth factor (EGF)-stimulated Ras activation in intact cells by a cell-permeable peptide mimicking phosphorylated EGF receptor. J Biol Chem 271: 27456-27461, 1996.

27. Martin S, Giannone G, Andriantsitohaina R and Martinez MC Delphinidin, an active compound of red wine, inhibits endothelial cell apoptosis via nitric oxide pathway and regulation of calcium homeostasis. Br J Pharmacol 139: 1095-1102, 2003.

28. Afaq F, Zaman N, Khan N, Syed DN, Sarfaraz S, Zaid MA and Mukhtar H: Inhibition of epidermal growth factor receptor signaling pathway by delphinidin, an anthocyanidin in pigmented fruits and vegetables. Int J Cancer 123: 1508-1515, 2008.

29. Semenza GL: HIF-1: mediator of physiological and pathophysiological responses to hypoxia. J Appl Physiol (1985) 88: 1474-1480, 2000.

30. Tong E, Xu Y, Li G, Zou K and Zou L: The effects of $\beta$-elemene on the expression of mTOR, HIF-1A, survivin in lung adenocarcinoma A549 cell. Afr J Tradit Complement Altern Med 10: $18-23,2013$

31. Lv L, Yuan J, Huang T, Zhang C, Zhu Z, Wang L, Jiang G and Zeng F: Stabilization of Snail by HIF- $1 \alpha$ and TNF- $\alpha$ is required for hypoxia-induced invasion in prostate cancer PC3 cells. Mol Biol Rep 41: 4573-4582, 2014.

32. Badr GA, Zhang JZ, Tang J, Kern TS and Ismail-Beigi F: Glut1 and glut 3 expression, but not capillary density, is increased by cobalt chloride in rat cerebrum and retina. Brain Res Mol Brain Res 64: 24-33, 1999.

33. Wang GL and Semenza GL: Characterization of hypoxia-inducible factor 1 and regulation of DNA binding activity by hypoxia. J Biol Chem 268: 21513-21518, 1993.

34. Epstein AC, Gleadle JM, McNeill LA, Hewitson KS, O'Rourke J, Mole DR, Mukherji M, Metzen E, Wilson MI, Dhanda A, et al: C. elegans EGL-9 and mammalian homologs define a family of dioxygenases that regulate HIF by prolyl hydroxylation. Cell 107: 43-54, 2001.

35. Yuan Y, Hilliard G, Ferguson T and Millhorn DE: Cobalt inhibits the interaction between hypoxia-inducible factor-alpha and von Hippel-Lindau protein by direct binding to hypoxia-inducible factor-alpha. J Biol Chem 278: 15911-15916, 2003.

36. Afaq F, Zaman N, Khan N, Syed DN, Sarfaraz S, Zaid MA and Mukhtar H: Inhibition of epidermal growth factor receptor signaling pathway by delphinidin, an anthocyanidin in pigmented fruits and vegetables. Int J Cancer 123: 1508-1515, 2008.

37. Marhold M, Tomasich E, El-Gazzar A, Heller G, Spittler A, Horvat R, Krainer M and Horak P: HIF1 $\alpha$ regulates mTOR signaling and viability of prostate cancer stem cells. Mol Cancer Res 13: 556-564, 2015 .

38. Park SJ, Ryu J, Kim IH, Choi YH and Nam TJ: Activation of the mTOR signaling pathway in breast cancer MCF-7 cells by a peptide derived from Porphyra yezoensis. Oncol Rep 33: 19-24, 2014.

39. Jefferies HB, Fumagalli S, Dennis PB, Reinhard C, Pearson RB and Thomas G: Rapamycin suppresses 5'TOP mRNA translation through inhibition of p70s6k. EMBO J 16: 3693-3704, 1997.

40. Minet E, Arnould T, Michel G, Roland I, Mottet D, Raes M, Remacle $\mathbf{J}$ and Michiels C: ERK activation upon hypoxia: Involvement in HIF-1 activation. FEBS Lett 468: 53-58, 2000.

41. Ozbay T and Nahta R: Delphinidin inhibits HER 2 and Erk1/2 signaling and suppresses growth of HER2-overexpressing and triple negative breast cancer cell lines. Breast Cancer (Auckl) 5: 143-154, 2011.

42. Kondo Y, Arii S, Mori A, Furutani M, Chiba T and Imamura M: Enhancement of angiogenesis, tumor growth, and metastasis by transfection of vascular endothelial growth factor into LoVo human colon cancer cell line. Clin Cancer Res 6: 622-630, 2000. 